\title{
Pendekatan Diagnosis dan Tata Laksana Acquired Immunodeficiency Syndrome [AIDS] pada Anak: laporan kasus
}

\author{
Ni Ketut Prami Rukmini, Nia Kurniati, Dadi Suyoko \\ Divisi Alergi-Imunologi Departemen Ilmu Kesehatan Anak Fakultas Kedokteran Universitas Indonesia, \\ RS Dr. Cipto Mangunkusumo, Jakarta
}

\begin{abstract}
Acquired immune deficiency syndrome (AIDS) pertama kali dilaporkan pada awal tahun 1980-an, merupakan infeksi human immunodeficiency virus (HIV). Penyakit ini telah menjadi pandemi yang meluas secara cepat khususnya di Afrika dan Asia. Pada tahun 2005 terdapat 40,3 juta orang di seluruh dunia hidup dengan HIV/AIDS, termasuk diantaranya 4,9 juta infeksi baru dan 3,1 juta tercatat meninggal dunia. ${ }^{1-3}$ Selama tahun 2005, diperkirakan 700.000 anak di seluruh dunia baru terinfeksi HIV. Sekitar 90\% memperoleh infeksi dari ibunya selama kehamilan, kelahiran atau menyusui. ${ }^{4,5}$ Di Rumah Sakit Cipto Mangunkusumo (RSCM) Jakarta, prevalens anak yang terinfeksi HIV 46 anak sepanjang tahun 2005. Manifestasi klinis HIV/AIDS ini bermacam-macam sesuai dengan derajat penyakit yang telah terjadi. ${ }^{5}$ Dijumpai beberapa sistem klasifikasi untuk mendiagnosis infeksi HIV pada anak sehingga diharapkan dapat menjadi pedoman tata laksana pasien HIV/AIDS. ${ }^{5-9}$ Tujuan laporan kasus ini untuk mendiskusikan tentang anak yang dicurigai terinfeksi HIV, bagaimana menegakkan diagnosis, dan tata laksana AIDS pada anak (Sari Pediatri 2007; 9(2):101-111).
\end{abstract}

Kata kunci: HIV, AIDS, anak, anti retro-virus

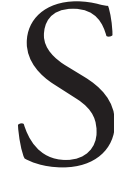
eorang anak laki-laki, G, berusia empat tahun, berobat ke Poliklinik Alergi dan Imunologi Anak RSCM Jakarta dengan keluhan utama mencret sejak delapan hari sebelum masuk rumah sakit. Sejak usia empat bulan pasien sering

\footnotetext{
Alamat korespondensi

Dr. Nia Kurniati, Sp.A.

Departemen Ilmu Kesehatan Anak FKUI-RSCM, Divisi Alergi-Imunologi.

Jl. Salemba 6, Jakarta 10430. Tel. 021-316 1144. Fax. 3913982
}

mencret, berat badan sulit naik dan sering batuk. Pasien baru bisa duduk saat umur 11 bulan, dapat berdiri saat umurnya satu tahun lima bulan. Pasien sering demam hilang timbul sejak umur sepuluh bulan.

Pasien pernah dikirim dari Departemen Kulit dan Kelamin RSCM ke Departemen IKA RSCM karena dermatitis seboroik dan limfadenopati et causa otitis media serosa dextra et sinistra. Anamnesis tambahan mendapatkan data orang tua dengan risiko tinggi terinfeksi HIV. Pemeriksaan fisis menunjukkan berat badan $7,9 \mathrm{~kg}\left(<\mathrm{P}_{3} \mathrm{NCHS}\right)$ serta klinis gizi buruk. 
Diagnosis saat masuk rumah sakit ialah diare kronik tanpa dehidrasi, demam berkepanjangan, riwayat limfadenopati, tersangka AIDS dan gizi buruk tipe marasmik. Pasien direncanakan dirawat, tetapi nenek yang membawa pasien meminta untuk menunda perawatan dengan alasan akan meminta ijin dahulu kepada keluarga. Dua bulan yang lalu, pasien datang kembali dengan membawa hasil serologi anti HIV (penyaring) yang menunjukkan reaktif dan didiagnosis HIV kategori C. Pasien mulai diterapi anti retro virus (ARV) yaitu zidovudin, lamivudin, nevirapin, kotrimoksasol dan nistatin per oral.

Riwayat penyakit keluarga menunjukkan bahwa ayah pasien telah meninggal pada tahun 2000 kemungkinan karena penyakit hepatitis. Ayah pasien juga seorang pecandu narkoba jenis suntikan. Ibu pasien sering berganti-ganti pasangan setelah ayahnya meninggal.

Selama hamil ibu memeriksakan kehamilannya secara teratur di bidan. Pasien lahir spontan, cukup bulan, ditolong bidan, langsung menangis, berat lahir 2800 gram dan panjang lahir lupa. Pasien tidak memperoleh imunisasi dasar yang lengkap.

Pada pemeriksaan fisis terlihat keadaan umum anak tampak sakit sedang, sadar, tidak sesak dan tidak sianosis. Tanda vital dalam batas normal. Status antropometri menunjukkan berat badan $8,5 \mathrm{~kg}\left(<\mathrm{P}_{3}\right.$ $\mathrm{NCHS})$, panjang badan $90 \mathrm{~cm}\left(\mathrm{P}_{3} \mathrm{NCHS}\right)$, lingkar kepala $49 \mathrm{~cm}$ (normal), klinis menunjukkan gizi buruk tipe marasmik. Pemeriksaan kepala menunjukkan tidak ada deformitas, normosefal, rambut hitam, tipis dan tidak mudah dicabut. Wajah tampak seperti orang susah. Pada pemeriksaan mata tidak didapatkan xerosis konjungtiva. Palpebra tampak cekung. Kelenjar getah bening leher teraba multipel dengan ukuran berkisar $1-2 \times 1 \times 1 \mathrm{~cm}^{3}$, kenyal, dapat digerakkan, tidak nyeri tekan dan tidak didapatkan kaku kuduk. Pemeriksaan telinga, hidung dan tenggorokan menunjukkan tidak ada kelainan. Pemeriksaan jantung, paru dan abdomen dalam batas normal. Pemeriksaan ekstremitas menunjukkan wasting dan hipotrofi, teraba hangat dan perfusi perifer baik. Pemeriksaan motorik terdapat hipotonia pada keempat ekstremitas.

Pemeriksaan darah perifer lengkap menunjukkan $\mathrm{Hb}$ 6,7 g/dL, leukosit 6400/Ul, trombosit 382.000/ $\mathrm{uL}$ dengan hitung jenis (\%) segmen 28, limfosit 68 dan monosit 4. Pemeriksaan analisis gas darah dalam batas normal. Dilakukan pemeriksaan limfosit $\mathrm{T}$ total 6187 (690-2540) dan T helper 394 (410-1540).
Pada saat itu ditegakkan diagnosis kerja AIDS/HIV kategori $\mathrm{C}$, disertai diare melanjut dehidrasi ringan sedang, gizi buruk tipe marasmik, perkembangan terlambat, gagal tumbuh dan pembesaran kelenjar getah bening leher. Kombinasi cairan rehidrasi oral dan intravena serta antibiotik metronidazol untuk kecurigaan adanya bakteri tumbuh lampau. Untuk gizi buruk diberikan formula $75 \mathrm{WHO}$, vitamin A, asam folat, $\mathrm{MgSo} 4$ 40\% intramuskular selama 5 hari dan ZnSo4 per oral selama satu minggu. Pemberian terapi ARV dilanjutkan, serta diberikan profilaksis untuk infeksi oportunistik dengan pemberian kotrimoksasol.

Perbaikan klinis ditemukan pada perawatan minggu pertama, diare berkurang, demam mulai menghilang serta berat badan mulai naik. Hasil biakan feses menunjukkan adanya Acinetobacter calcoaceticus dan parasit feses menunjukkan Blastocystis hominis. Saat itu metronidazol dihentikan dan diberikan antibiotik seftriakson dan albendazol intravena. Pada minggu kedua perawatan klinis pasien memburuk, mencret bertambah banyak, demam masih naik turun, dan mengalami syok hipovolemik dua kali. Akhirnya keluarga membawa pasien pulang atas permintaan sendiri dalam keadaan diare dengan dehidrasi ringan. Namun secara klinis selama di rumah tidak ada perbaikan dan akhirnya meninggal dunia.

\section{Diskusi}

Selama tahun 2005 di seluruh dunia, diperkirakan infeksi baru HIV 700.000 anak. Lebih dari 80\% kasus tersebut terjadi di Sub-Sahara Afrika, meskipun di Asia dan Karibia juga didapatkan peningkatan jumlah anak yang terinfeksi HIV. ${ }^{4,5,10}$ Sekitar 90\% anak-anak tersebut memperoleh infeksi dari ibunya selama kehamilan, kelahiran atau menyusui. ${ }^{4,5,11}$ Di Amerika, sekitar 6000 bayi lahir tiap tahun dari ibu yang terinfeksi HIV ${ }^{12}$ dan setiap hari diperkirakan lebih dari 8200 orang meninggal karena AIDS. Keseluruhan kasus HIV, 1400 anak tanpa terapi ARV sehingga anak HIV akan meninggal pada usia kurang dari lima tahun. ${ }^{13}$ Sekitar $80 \%$ dari semua anak AIDS telah didiagnosis AIDS sebelum usia lima tahun. ${ }^{14}$

Virus HIV merupakan lentivirus, subfamili retrovirus. Dijumpai dua jenis virus utama, yaitu HIV-1 dan HIV-2, dan beberapa subtipe dari tiap-tiap jenis virus. HIV-1 secara prevalens paling banyak ditemukan di seluruh dunia, sementara HIV-2 terutama dijumpai di Afrika Barat. ${ }^{15-8}$ 
Ni Ketut Prami Rukmini dkk: Pendekatan Diagnosis dan Tata Laksana Acquired Immunodeficiency Syndrome (Aids) pada Anak: Laporan Kasus

Tabel 1. Algoritme dugaan seorang anak terinfeksi HIV berdasarkan World Health Organization ${ }^{8}$

\begin{tabular}{|c|c|}
\hline Pertanyaan & Mereka terlihat dan merasakan \\
\hline $\begin{array}{l}\text { - Apakah seorang anak memiliki riwayat infeksi } \\
\text { paru yang membutuhkan rawat inap selama } \\
\text { tiga bulan terakhir? } \\
\text { - Apakah seorang anak memiliki dua atau lebih } \\
\text { episode diare selama tiga bulan terakhir? } \\
\text { - Apakah seorang anak pernah memiliki episode } \\
\text { diare persisten (berakhir lebih dari } 14 \text { hari) } \\
\text { selama tiga bulan terakhir? } \\
\text { - Apakah seorang anak memiliki nafsu makan } \\
\text { yang buruk? } \\
\text { - Apakah seorang anak memiliki riwayat infeksi } \\
\text { telinga kronik (cairan dari telinga selama } 14 \\
\text { hari)? } \\
\text { - Apakah seorang anak memiliki riwayat atau } \\
\text { terbukti sedang terinfeksi herpes zoster? } \\
\text { Apakah ada riwayat atau sedang menderita } \\
\text { tuberkulosis? } \\
\text { Apakah orang tua atau saudaranya ada yang } \\
\text { diketahui menderita tuberkulosis? } \\
\text { Apakah orang tua atau saudaranya ada yang } \\
\text { diketahui terinfeksi HIV? }\end{array}$ & $\begin{array}{l}\text { - Apakah berat badan anak di bawah } \\
\text { persentil tiga? } \\
\text { - Apakah seorang anak memiliki riwayat dari } \\
\text { catatan kartu berobat atau dari standar } \\
\text { kurva pertumbuhan berat badan yang sulit } \\
\text { naik? } \\
\text { - Apakah seorang anak memiliki pembesaran } \\
\text { kelenjar getah bening di satu atau lebih } \\
\text { tempat berikut : leher, ketiak atau groin? } \\
\text { - Apakah ada oral thrush yang menyebar ke } \\
\text { arah belakang mulut atau tenggorokan? }\end{array}$ \\
\hline
\end{tabular}

Virus HIV menginfeksi manusia dengan cara melekatkan protein permukaan HIV-1 (gp 120) pada reseptor HIV yang terdapat di permukaan sel T CD4. Setelah berhasil masuk ke dalam sel T, materi genetik HIV ribonucleic acid (RNA) akan mengalami transkripsi balik dengan bantuan enzim reverse transcriptase (RT) akan menjadi deoxy ribonuclic acid (DNA) intermediate (complementary DNA/cDNA). Selanjutnya DNA berintegrasi dengan DNA inti sel T CD4 setiap kali terjadi mitosis dan meiosis. ${ }^{5,15-7}$

Manifestasi klinis HIV bervariasi dari satu anak dengan yang lain, sebagian besar bayi mempunyai gejala yang berhubungan dengan HIV mulai usia 12 bulan, sebagian terinfeksi selama kehamilan atau proses kelahiran. Manifestasi yang paling sering diantaranya gagal tumbuh, hepatosplenomegali, infeksi berulang (khususnya pneumonia), Pneumocystis carinii pneumonia, diare, kandidiasis oral, limfadenopati, kemerahan pada kulit, ensefalopati, parotitis, demam yang menetap, lymphocytic interstitial pneumonitis (LIP) dan infeksi bakteri berulang serta infeksi serius oleh kuman oportunistik (aspergillosis, candidiasis, cryptococcosis, cytomegalovirus, norcardiosis, strongyloidosis, toxoplasmosis, zygomycosis, or atypical mycobacteriosis dan lainlain). ${ }^{5,8,20,21-3}$ Infeksi paru paling sering terjadi dan menyebabkan kematian pada pasien HIV. Manifestasi yang paling sering pada anak AIDS adalah LIP sekitar $40 \%$ anak yang terinfeksi HIV. ${ }^{5,6}$

Berdasarkan banyaknya manifestasi klinis yang dapat dicurigai pada seorang anak menderita HIV, maka WHO membuat suatu algoritma dugaan seorang anak terinfeksi HIV sehingga lebih mudah terdeteksi.

Ada banyak sistem klasifikasi infeksi HIV antara lain berdasarkan gejala klinis dan jumlah limfosit $\mathrm{T}$. World Health Organization dan Centers for Disease Control and Prevention membuat kategori manifestasi klinis infeksi HIV pada anak. Masing-masing klasifikasi memiliki keuntungan dan kerugian. Klasifikasi menurut WHO mudah digunakan dan lebih berdasarkan manifestasi klinis daripada uji laboratorium, sehingga dipilih untuk daerah dengan ketersediaan sarana diagnosis terbatas. Klasifikasi tersebut tidak 
menunjukkan variasi manifestasi klinis yang luas pada anak terinfeksi HIV. Klasifikasi WHO tidak memasukkan kategori E dari klasifikasi CDC yaitu untuk bayi yang terpapar infeksi HIV tetapi status imun masih belum jelas. Sistem klasifikasi WHO (Lampiran 1) pada anak dibagi menjadi empat derajat (I, II, III dan IV) sesuai dengan progresifitas yang lebih berat dan prognosis yang lebih buruk. Klasifikasi CDC (Lampiran 2) lebih dihubungkan dengan kategori status imun, manifestasi klinis berdasarkan berat penyakit dan luas diagnosis. Pada anak AIDS disertai infeksi oportunistik akan selalu dikategorikan WHO kategori III atau CDC kategori C. Masing-masing boleh memilih mana yang akan digunakan, tetapi harus konsisten. Bila sejak awal menggunakan kriteria CDC, selanjutnya dengan CDC dan sebaliknya.-8

Bila seorang anak pernah diklasifikasikan dalam suatu kategori maka tidak akan diklasifikasikan dengan kategori yang lebih rendah walaupun ada kemajuan klinis atau status imunologis sebagai respons terapi ARV atau faktor lain. Bila seseorang memiliki kriteria klinis lebih banyak sesuai untuk kategori B tetapi ada satu yang $\mathrm{C}$, maka anak tersebut dikategorikan HIV kategori C. ${ }^{8,24}$ Telah dibuat beberapa sistem diagnosis WHO kemungkinan infeksi HIV pada anak hanya berdasarkan gejala klinis. Salah satu sistem diagnosis berdasarkan gejala dan tanda dalam kriteria mayor dan minor (Tabel 2). Anak yang memiliki sedikitnya dua gejala mayor dan dua minor dapat didiagnosis dengan HIV, walaupun tanpa uji laboratorium HIV. ${ }^{8}$

Pada pasien ini awalnya didapatkan gejala berupa anemia, demam yang berulang dan menetap, kandidiasis oral yang berulang, diare persisten berulang, gagal tumbuh, perkembangan terlambat.
Dijumpai riwayat pembesaran kelenjar getah bening leher, status gizi buruk tipe marasmik, serta dari analisis feses ditemukan $B$. hominis yang merupakan kuman oportunistik. Infeksi HIV belum dipikirkan pada awal manifestasi morbiditas (dua tahun yang lalu) karena infeksi HIV belum umum (familiar). Seiring perkembangan waktu, dengan makin banyaknya orang dewasa pemakai obat terlarang jenis suntikan ataupun yang berganti-ganti pasangan, anak-anak yang lahir dari pasangan berisiko ini semakin mungkin terinfeksi HIV. Dilihat dari manifestasi klinis yang ada maka pasien ini dapat digolongkan sebagai HIV kategori C atau WHO stadium 4 dengan AIDS. Status imunosupresi belum diketahui karena jumlah CD4+ saat awal belum diperiksa.

Saat HIV masuk ke dalam tubuh, sistem imun membuat antibodi terhadap HIV. Sebagai uji penyaring menggunakan Enzyme Linked Immunosorbent assay (ELISA) dan sebagai uji konfirmasi dengan Western Blot. Kedua uji berfungsi untuk mendeteksi adanya antibodi terhadap HIV, namun Western Blot lebih spesifik mendeteksi antibodi terhadap komponen antigen permukaan virus Pemeriksaan lainnya yang dapat dilakukan adalah dengan memeriksa materi genetik (RNA) HIV dengan pemeriksaan polymerase chain reactions (viral load) yang dapat mendeteksi ada tidaknya RNA HIV dan berapa jumlah virus (jumlah kopi RNA virus) yang terdapat dalam darah. ${ }^{18-9,26-7}$ Bayi yang baru lahir dari ibu yang terinfeksi HIV-1 sebaiknya diperiksa PCR DNA HIV-1 sebelum usia 28 jam dan diulang selama bulan pertama kehidupan untuk meyakinkan identifikasi awal dan tata laksana lebih lanjut. ${ }^{28-30}$ Sebelum melakukan pemeriksaan untuk diagnosis HIV ini pasien harus diberikan informasi dan konseling dahulu.?

Tabel 2. Kriteria klinis diagnosis HIV pada anak berdasarkan $\mathrm{WHO}^{25}$

\begin{tabular}{ll}
\hline \multicolumn{1}{c}{ Gejala mayor (minimal 2 gejala) } & \multicolumn{1}{c}{ Gejala minor (minimal 2 gejala) } \\
\hline - Penurunan berat badan atau pertumbuhan & - Pembesaran kelenjar getah bening generalisata \\
yang lambat & - Kandidiasis orofarings \\
- Diare kronis $(>1$ bulan) & - Infeksi yang berulang (misalnya infeksi \\
- Demam berkepanjangan tanpa sebab yang & telinga, faringitis) \\
- jelas (>1 bulan) & - Batuk persisten (tanpa adanya penyakit \\
- Pneumonia berat atau berulang & tuberkulosis) \\
& - Ruam generalisata \\
& - Infeksi HIV maternal
\end{tabular}

AIDS didefinisikan apabila ditemukan minimal 2 atau lebih gejala mayor dan 2 atau lebih gejala minor tanpa ada penyebab supresi imun yang lain. 
menunjukkan variasi manifestasi klinis yang luas pada anak terinfeksi HIV. Klasifikasi WHO tidak memasukkan kategori E dari klasifikasi CDC yaitu untuk bayi yang terpapar infeksi HIV tetapi status imun masih belum jelas. Sistem klasifikasi WHO (Lampiran 1) pada anak dibagi menjadi empat derajat (I, II, III dan IV) sesuai dengan progresifitas yang lebih berat dan prognosis yang lebih buruk. Klasifikasi CDC (Lampiran 2) lebih dihubungkan dengan kategori status imun, manifestasi klinis berdasarkan berat penyakit dan luas diagnosis. Pada anak AIDS disertai infeksi oportunistik akan selalu dikategorikan WHO kategori III atau CDC kategori C. Masing-masing boleh memilih mana yang akan digunakan, tetapi harus konsisten. Bila sejak awal menggunakan kriteria CDC, selanjutnya dengan CDC dan sebaliknya.-8

Bila seorang anak pernah diklasifikasikan dalam suatu kategori maka tidak akan diklasifikasikan dengan kategori yang lebih rendah walaupun ada kemajuan klinis atau status imunologis sebagai respons terapi ARV atau faktor lain. Bila seseorang memiliki kriteria klinis lebih banyak sesuai untuk kategori B tetapi ada satu yang $\mathrm{C}$, maka anak tersebut dikategorikan HIV kategori C. ${ }^{8,24}$ Telah dibuat beberapa sistem diagnosis WHO kemungkinan infeksi HIV pada anak hanya berdasarkan gejala klinis. Salah satu sistem diagnosis berdasarkan gejala dan tanda dalam kriteria mayor dan minor (Tabel 2). Anak yang memiliki sedikitnya dua gejala mayor dan dua minor dapat didiagnosis dengan HIV, walaupun tanpa uji laboratorium HIV. ${ }^{8}$

Pada pasien ini awalnya didapatkan gejala berupa anemia, demam yang berulang dan menetap, kandidiasis oral yang berulang, diare persisten berulang, gagal tumbuh, perkembangan terlambat.
Dijumpai riwayat pembesaran kelenjar getah bening leher, status gizi buruk tipe marasmik, serta dari analisis feses ditemukan $B$. hominis yang merupakan kuman oportunistik. Infeksi HIV belum dipikirkan pada awal manifestasi morbiditas (dua tahun yang lalu) karena infeksi HIV belum umum (familiar). Seiring perkembangan waktu, dengan makin banyaknya orang dewasa pemakai obat terlarang jenis suntikan ataupun yang berganti-ganti pasangan, anak-anak yang lahir dari pasangan berisiko ini semakin mungkin terinfeksi HIV. Dilihat dari manifestasi klinis yang ada maka pasien ini dapat digolongkan sebagai HIV kategori C atau WHO stadium 4 dengan AIDS. Status imunosupresi belum diketahui karena jumlah CD4+ saat awal belum diperiksa.

Saat HIV masuk ke dalam tubuh, sistem imun membuat antibodi terhadap HIV. Sebagai uji penyaring menggunakan Enzyme Linked Immunosorbent assay (ELISA) dan sebagai uji konfirmasi dengan Western Blot. Kedua uji berfungsi untuk mendeteksi adanya antibodi terhadap HIV, namun Western Blot lebih spesifik mendeteksi antibodi terhadap komponen antigen permukaan virus Pemeriksaan lainnya yang dapat dilakukan adalah dengan memeriksa materi genetik (RNA) HIV dengan pemeriksaan polymerase chain reactions (viral load) yang dapat mendeteksi ada tidaknya RNA HIV dan berapa jumlah virus (jumlah kopi RNA virus) yang terdapat dalam darah. ${ }^{18-9,26-7}$ Bayi yang baru lahir dari ibu yang terinfeksi HIV-1 sebaiknya diperiksa PCR DNA HIV-1 sebelum usia 28 jam dan diulang selama bulan pertama kehidupan untuk meyakinkan identifikasi awal dan tata laksana lebih lanjut. ${ }^{28-30}$ Sebelum melakukan pemeriksaan untuk diagnosis HIV ini pasien harus diberikan informasi dan konseling dahulu.?

Tabel 2. Kriteria klinis diagnosis HIV pada anak berdasarkan $\mathrm{WHO}^{25}$

\begin{tabular}{ll}
\hline \multicolumn{1}{c}{ Gejala mayor (minimal 2 gejala) } & \multicolumn{1}{c}{ Gejala minor (minimal 2 gejala) } \\
\hline - Penurunan berat badan atau pertumbuhan & - Pembesaran kelenjar getah bening generalisata \\
yang lambat & - Kandidiasis orofarings \\
- Diare kronis $(>1$ bulan) & - Infeksi yang berulang (misalnya infeksi \\
- Demam berkepanjangan tanpa sebab yang & telinga, faringitis) \\
- jelas (>1 bulan) & - Batuk persisten (tanpa adanya penyakit \\
- Pneumonia berat atau berulang & tuberkulosis) \\
& - Ruam generalisata \\
& - Infeksi HIV maternal
\end{tabular}

AIDS didefinisikan apabila ditemukan minimal 2 atau lebih gejala mayor dan 2 atau lebih gejala minor tanpa ada penyebab supresi imun yang lain. 
Mengingat tidak semua pusat kesehatan memiliki sarana untuk pemeriksaan serta tenaga ahli yang sesuai untuk menentukan diagnosis dan derajat klinik infeksi, dibuatlah suatu cara untuk menentukan diagnosis yang disesuaikan dengan sarana, prasarana serta sumber daya yang tersedia. Anak tersebut harus diklasifikasikan ke dalam sistem klasifikasi berdasarkan jumlah limfosit CD4 dan manifestasi klinisnya. Jumlah dan persentase sel CD4 akan memberikan gambaran supresi imun pada anak. Status penyakit dapat diklasifikasikan dengan derajat imunosupresi (1,2, atau 3) dan kategori klinis (N,A,B,C atau E). ${ }^{5,8,24}$

Selain cara klasifikasi seperti yang telah disebutkan, terdapat sistem klasifikasi HIV berdasarkan kategori imun, sehingga didapatkan data mengenai tingkat supresi imun, terutama untuk pusat kesehatan yang memiliki sumber daya yang lengkap. Sistem klasifikasi HIV berdasarkan kategori imun ini, berdasarkan jumlah dan presentase sel $\mathrm{T}$ limfosit CD4 sesuai dengan usia (Tabel 4).

Pada pasien ini awalnya belum diperiksa jumlah dan persentase CD4-nya karena nenek sebagai pengganti orang tua saat itu tidak memiliki uang.

Pemberian terapi ARV harus dilakukan dengan persiapan yang kompleks berupa konseling tentang keamanan, efek samping dan ketidakpatuhan pengobatan yang dapat menyebabkan kegagalan terapi karena diberikan jangka panjang. Pemberian ARV dapat menurunkan jumlah virus yang beredar dalam darah, menurunkan insidens infeksi oportunistik pada AIDS, menurunkan rerata kematian karena AIDS, perbaikan klinis dari infeksi

Tabel 5. Indikasi mulai pemberian terapi anti retroviral pada anak. ${ }^{5}$

Anak-anak usia $<12$ bulan

- Gagal tumbuh (tidak ada peningkatan berat badan atau kehilangan berat badan atau skor $Z<-2)$

- Penyakit dengan gejala yang berat (WHO derajat II, CDC kategori $\mathrm{B}^{*}$ )

- Klinis sesuai AIDS (WHO III, CDC kategori C)

- Anak dengan persentase CD $4<20 \%$

Anak usia 1-12 tahun

- Gagal tumbuh (tidak ada peningkatan berat badan atau kehilangan berat badan atau skor $\mathrm{Z}<-2$ )

- Penyakit dengan gejala yang advance (WHO derajat II, CDC kategori $\mathrm{B}^{*}$ )

- Klinis sesuai AIDS (WHO III, CDCkategori C)

- Anak dengan persentase CD $4<15 \% * *$

Anak usia $\geq 13$ tahun (sebagai tatalaksana dewasa***)

- WHO penyakit derajat 4 (klinis AIDS) irespektif jumlah sel CD4

- WHO penyakit derajat 3 dan $\mathrm{CD} 4 \leq 350$

- $\mathrm{CD} 4 \leq 200$ irespektif derajat WHO

* Beberapa yang didiagnosis kategori B mungkin tidak anjurkan ART kecuali juga ada bukti supresi imun. Secara khusus, abnormalitas sumsum tulang ringan atau episode tunggal pneumonia mungkin belum membutuhkan ART. Hal yang serupa dengan tatalaksana WHO menyebutkan persentase CD4 saat memutuskan memulai ART diindikasikan untuk derajat II. Ketajaman klinis harus seimbang dengan keuntungan tatalaksana dengan toksisitas jangka panjang dan tantangan akan kepatuhannya.

** Pada anak usia $=6$ tahun, dokter mungkin mempertimbangkan menunda sampai CD4 mencapai $10 \%$, atau sampai ada bukti adanya kemunduran imunitas yang cepat. Bila tidak ada data, beberapa usulan menyatakan bahwa kesulitan dalam memelihara kepatuhan anak dan potensi toksisitas ART lebih buruk daripada pemberian laksana lebih awal. Bila tatalaksananya ditunda pada keadaan ini, kami merekomendasikan pemantauan jumlah /\% CD4 lebih sering (tiap 3 tau 4 bulan.

*** ICAP merekomendasikan bahwa remaja usia $=13$ tahun mengikuti tatalaksana dewasa untuk kemungkinan/kemudahan tata laksana eligibility. Keputusan tentang apakah memulai regimen untuk anak atau dewasa dan dosisnya seharusnya berdasarkan kematangan fisik (dengan tanner staging) daripada penilaian usia. 
oportunistik tanpa terapi antibiotika khusus, dan lainlain. Sampai saat ini, keputusan memulai pemberian obat antiretroviral masih beragam, dimulai dari seluruh bayi yang terinfeksi HIV harus memulai ARV, adanya gejala klinis atau adanya bukti supresi imun. ${ }^{5,37-8}$ Pada Tabel 5 tertera indikasi pemberian ARV berdasarkan umur.

Pada pasien ini, pemberian ARV dimulai berdasarkan kondisi klinis pasien saat itu, yaitu HIV positif dengan gejala yang berat, walaupun saat itu tidak ada data awal mengenai jumlah CD4. Setelah orang yang bertanggung jawab terhadap pasien dalam hal ini nenek pasien (caretaker) mengerti, memahami dan menandatangani pernyataan untuk memulai pemberian ART barulah mulai diberikan ARV.

Regimen awal diberikan sesuai dengan umur pasien, - Anak usia $\leq 3$ tahun:

- Zidovudin + lamivudin + nevirapin

- $\quad$ Stavudin + lamivudin + nevirapin

- Anak usia $\geq 3$ tahun $\geq 10 \mathrm{~kg}$ :

- Zidovudin + lamivudin + nevirapin atau efavirens

- Stavudin + lamivudin + nevirapin atau efavirens

Pada pasien ini dimulai dengan pemberian zidovudin, lamivudin dan nevirapin sesuai dengan anjuran regimen pemberian ARV pada anak usia lebih dari 3 tahun.

Deteksi dini HIV pada anak penting dilakukan agar dapat diberikan tata laksana yang sesuai sehingga memberikan prognosis yang lebih baik.

\section{Daftar Pustaka}

1. Epidemic update: Desember 2000. Diunduh dari http:/ Iwww.unaids.org/wac/2000/wadoo/files/WAD_ epidemic_report.htm. Diakses pada tanggal 25 November 2005.

2. Aulock SV, Hartung T. Potential for immune reconstitution through G-CSF treatment of HIV patients. Arch Immunol Ther Experiment 2002; 50:111-20.

3. World HIV \& AIDS statistics. Diunduh dari http:// www.avert.org/worldstats.htm. Diakses pada tanggal 25 November 2005.

4. Children, HIV and AIDS. Diunduh dari http:// www.avert.org/children.htm. Diakses pada tanggal 25 November 2005.
5. Abrams E, El-Sadr W, Rabkin M. The pediatric clinical manual: the international center for AIDS programs. New York, Columbia University Mailman School of Public Health, 2004.h.33-5.

6. Imaging of chest disease in children with AIDS. Diunduh dari http://www.medscape.com/viewarticle/416681_print. Diakses pada tanggal 25 November 2005.

7. The official U.S. Government Definition of "AIDS" (1993). Diunduh dari http://www.aegis.com/topics/ definition.html. pada tanggal 25 November 2005.

8. HIV/AIDS diagnostic criteria. Diunduh dari http:// www.go2itech.org. Diakses pada tanggal 25 November 2005.

9. HIV prevention counseling. Diunduh dari http:// www.go2itech.org. Diakses pada tanggal 5 November 2005.

10. Trends in HIV/AIDS diagnosis - 33 states 2001-2004. Diunduh dari http://www.cdc.gov/mmwr/preview/ mmwrhtml/mm5445a1.htm. Diakses tanggal 25 November 2005.

11. Guidelines for national human immunodeficiency virus case surveillance, including monitoring for human immunodeficiency virus infection and acquired immunodeficiency syndrome. Diunduh dari http:// www.cdc.gov/mmwr/preview/mmwrhtml/rr4813a1.htm. Diakses pada tanggal 25 November 2005.

12. Pediatric AIDS: factors in transmission and pathogenesis. Diunduh dari http://grants.nih.gov/grants/guide/rfa-files/ RFA-AI-94-029.html. Diakses pada tanggal 25 November 2005.

13. World Health Organization: Regional Office for Western pasific. Antiretroviral therapy for children with HIV infection in resource-limited settings. Part I: initiating and changing therapy.Vol11, July 2005.h.1

14. AIDS among children. Diunduh dari http://www. thebody.com/cdclchildren.html. Diakses pada tanggal 25 November 2005.

15. What is AIDS? Diunduh dari http://www.pedaids.org/ AboutPediatricAIDS/WhatIsAids/WhatisAIDS.aspx. Diakses pada tanggal 25 November 2005.

16. STOP AIDS project. AIDS definition. Diunduh dari http:/ lwww.stopaids.org/resources/std_infolaids_definition.html. Diakses pada tanggal 25 November 2005.

17. HIV infection and AIDS. Diunduh dari http:// www.emedicine.com/emerg/topic253.htm. Diakses pada tanggal 25 November 2005.

18. Ammann AJ. Pediatric human immunodeficiency virus infection. Dalam: Stiehm ER, Ochs HD, Winkelstein JA, penyunting. Immunologic disorders in infants \& children. United States of America:Elsevier Saunders, 2004.h.878-951. 
19. Human immunodeficiency virus infection. Diunduh dari http://www.emedicine.com/ped/topic1027.htm. Diakses pada tanggal 25 November 2005.

20. Pancharoen C, Thisyakorn U. HIV/AIDS in children. Ann Acad Med Singapore 2003;32:235-8.

21. Recomendation for managing HIV infection in children. Diunduh dari http://www.doh.gov.zalaids/docs/ recommendations.html. Diakses tanggal 25 November 2005.

22. The envolving definition of AIDS. Diunduh dari $h t t p: /$ lwww.virusmyth.netlaids/datalrrbdef.htm. Diakses pada tanggal 25 November 2005.

23. Case definition of AIDS. Diunduh dari http:// www.gaylib.com/aids/aids24.htm. Diakses pada tanggal 25 November 2005.

24. Official Authorized Addenda: Human Immunodeficiency Virus Infection Codes and Officials Guidelines for Coding and Reporting ICD-9-CM. 1994 Revised classification system for human immunodeficiency virus infection in children less than 13 years of age. Atlanta:United States Department of Health and Human Services, Public Health Service, Centers for Disease Control and Prevention,1994.p.1-19.

25. Tindyebwa D, Kayita J, Musoke P, Eley B, Nduati R, Codradia H, dkk. Diagnosis and clinical staging of HIV infection. Dalam: Tindyebwa D, Kayita J,
Musoke P, Eley B, Nduati R, Codradia H, dkk, penyunting. Handbock paediatric AIDS in Africa. African Network for the Care of Children Atlected by AIDS, 2004.h.73-90.

26. HIV/AIDS or STD Directorate Department of Health. Managing HIV in children. South Africa:Department of Health South Africa,2000.p.1-41.

27. Concerns about HIV/AIDS testing and measurement. Diunduh dari http://www.virusmyth.net/aids/datal dctest.htm. Diakses pada tanggal 25 November 2005.

28. Luzuriaga K, Sullivan JR. Prevention and treatment of pediatric HIV infection. JAMA 1998;280:17-8.

29. American Academy of Pediatric, Canadian Paediatric Society. Evaluation and treatment of the human immunodeficiency virus -1-exposed infant. Pediatrics 2004; 114:497-505.

30. Benjamin DK Jr, Miller WC, Fiscus SA, Benjamin DK, Morse M, Valentine M. Rational testing of the HIVexposed infant. Pediatrics 2001;108:3-5.

31. Shearer WT, Quinn TC, LaRussa P, Lew JF, Mofenson L, Almy S. Viral load and disease proggression in infants infected with human immunodeficiency virus type 1 . NEJM.1997;336:1337-42.

32. Advances in antiretroviral therapy in HIV-1 disease. Diunduh dari http://www.medscape.com/viewarticle/ 416953_print. Diakses pada tanggal 25 November 2005. 
Lampiran 1. Derajat HIV/AIDS pada anak menurut WHO. ${ }^{25}$

\begin{tabular}{|c|c|}
\hline $\begin{array}{l}\text { WHO } \\
\text { Anak } \\
\text { Derajat } 1\end{array}$ & $\begin{array}{l}\text { Tanpa gejala } \\
\text { Limfadenopati generalisata yang menetap } \\
\text { Hepatosplenomegali }\end{array}$ \\
\hline $\begin{array}{l}\text { WHO } \\
\text { Anak } \\
\text { Derajat } 2\end{array}$ & $\begin{array}{l}\text { Papular pruritic eruptions } \\
\text { Dermatitis seboroik } \\
\text { Infeksi kuku oleh jamur } \\
\text { Angular chelitis } \\
\text { Lineal gingival erythema } \\
\text { HPV luas atau infeksi oleh moluskum ( }>5 \% \text { permukaan tubuh/wajah) } \\
\text { Ulserasi mulut berulang } \\
\text { Pembesaran kelenjar parotis } \\
\text { Herpes zoster ( }>1 \text { episode/12 bulan) }\end{array}$ \\
\hline $\begin{array}{l}\text { WHO } \\
\text { Anak } \\
\text { Derajat } 3\end{array}$ & $\begin{array}{l}\text { Infeksi kronik atau berulang saluran napas atas, otitis media, otorea, sinusitis ( }>2 \text { episode/6 bulan) } \\
\text { Malnutrisi sedang yang tidak dapat dijelaskan }(-2 \mathrm{SD} \text { atau } \mathrm{Z} \text { score) tidak respons terhadap terapi standar } \\
\text { Diare persisten yang tidak dapat dijelaskan }(>14 \text { hari) } \\
\text { Demam menetap yang tidak dapat dijelaskan (intermiten atau konstan, }>1 \text { bulan) } \\
\text { Kandidiasis oral (diluar periode neonatus) } \\
\text { Oral hairy leukoplakia } \\
\text { Tuberkulosis pulmonar } \\
\text { Diperkirakan pneumonia bakterial berat berulang ( }>2 \text { episode/12 bulan) } \\
\text { Acute necrotizing ulcerative gingivitis/periodonitis } \\
\text { Lymphoid interstitial pneumonitis (LIP) } \\
\text { Anemia yang tidak dapat dijelaskan }(<8 \mathrm{mg} / \mathrm{dL}) \text {, netropenia }\left(<1.000 / \mathrm{mm}^{3}\right) \text {, atau trombositopenia } \\
\left(<50.000 / \mathrm{mm}^{3}\right) \text { selama }>1 \text { bulan } \\
\text { Kardiomiopati yang dihubungkan dengan HIV } \\
\text { Nefropati yang dihubungkan dengan HIV }\end{array}$ \\
\hline $\begin{array}{l}\text { WHO } \\
\text { Anak } \\
\text { Derajat } 4\end{array}$ & $\begin{array}{l}\text { Antibodi HIV positif bayi usia }<18 \text { bulan yang menampakkan gejala } \\
2 \text { atau lebih berikut ini: } \\
\text { Kandidiasis oral/rush } \\
\text { Pneumonia berat } \\
\text { Gagal tumbuh } \\
\text { Sepsis } \\
\text { Diperkirakan diagnosis penyakit derajat } 4 \text { pada yang antibodi HIV positif bayi usia }<18 \text { bulan } \\
\text { membutuhkan konfirmasi bila memungkinkan dengan tes virologi, atau dengan tes antibodi } \\
\text { setelah usia } 18 \text { bulan }\end{array}$ \\
\hline $\begin{array}{l}\text { WHO } \\
\text { Anak } \\
\text { Derajat } 4 \\
\text { (derajat yang manapun) }\end{array}$ & $\begin{array}{l}\text { Wasting berat yang tidak dapat dijelaskan atau malnutrisi berat (-3 SD atau skor Z) tidak respons } \\
\text { terhadap terapi standar } \\
\text { Pneumocystis pneumonia } \\
\text { Infeksi bakteri yang berat ( }>2 \text { episode/12 bulan, diluar pneumonia) } \\
\text { HSV kronik prolabial atau kutan (berakhir }>1 \text { bulan) } \\
\text { Tuberkulosis ekstrapulmonar } \\
\text { Sarkoma kaposi } \\
\text { Kandidiasis esofageal } \\
\text { Toksoplasmosis susunan saraf pusat } \\
\text { Meningitis kriptokokus } \\
\text { Mikosis endemik diseminata yang manapun } \\
\text { Kriptosporidiosis atau isosporiasis (dengan diare }>1 \text { bulan) } \\
\text { Infeksi CMV dari organ selain hati, limpa, kelenjar getah bening (dan usia onset }>1 \text { bulan) } \\
\text { Penyakit mikobakterial diseminata selain tuberkulosis } \\
\text { Kandida trakea, bronkus atau paru } \\
\text { Fistel rekto vesika didapat } \\
\text { Limfoma non Hodgkins sel B atau serebral } \\
\text { Leukoensefalopati multifokal progresif } \\
\text { Ensefalopati HIV }\end{array}$ \\
\hline
\end{tabular}


Lampiran 2. Kategori Klinis CDC untuk Bayi dan Anak. $4,7,23$

Kategori E : Bayi yang secara vertikal (transmisi dari ibu) terpapar infeksi HIV tetapi status imunnya masih belum jelas. Kategori N : Tanpa Gejala

Anak tanpa gejala-gejala dan tanda-tanda yang dipertimbangkan oleh karena infeksi HIV atau hanya satu dari kondisi pada daftar di Kategori A.

Kategori A : Gejala Ringan

Anak dengan kondisi dua atau lebih daftar berikut ini tetapi tanpa kondisi Kategori B dan C.

- Limfadenopati $(=0,5 \mathrm{~cm}$ pada lebih dari dua tempat; bilateral = satu tempat $)$

- Hepatomegali

- Splenomegali

- Dermatitis

- Parotitis

- Infeksi saluran napas atas berulang atau persisten, sinusitis, atau otitis media

Kategori B : Gejala Sedang

Anak dengan gejala lain dari Kategori A atau C yang menyertai infeksi HIV. Kondisi klinis yang termasuk Kategori B sebagai berikut:

- Anemia $(<8 \mathrm{mg} / \mathrm{dL})$, netropenia $\left(<1,000 / \mathrm{mm}^{3}\right)$, atau trombositopenia $\left(<100,000 / \mathrm{mm}^{3}\right)$ menetap $=30$ hari

- Meningitis bakterialis, pneumonia, atau sepsis (satu episode)

- Kandidiasis, orofaringeal (thrush), menetap (> dua bulan) pada anak > usia enam bulan

- Kardiomiopati

- Infeksi sitomegalovirus, dengan awitan sebelum usia satu bulan

- Diare, berulang atau kronis

- Hepatitis

- Stomatitis virus herpes simpleks (VHS), berulang (lebih dari dua episode dalam satu tahun)

- Bronkitis VHS, pneumonitis, atau esofagitis dengan awitan sebelum usia satu bulan

- Herpes zozter melibatkan paling tidak dua episode berbeda atau lebih dari satu dermatom

- Leiomiosarkoma

- Limfoid pneumonia interstisialis atau kompleks

- Nefropati

- Nokardiosis

- Demam persisten (selama > satu bulan)

- Toksoplasmosis, awitannya sebelum usia satu bulan

- Varisela, diseminata (cacar air dengan komplikasi)

Kategori C : Gejala Berat

- Infeksi bakteri yang serius, multipel atau berulang (yaitu, apapun kombinasinya, paling tidak sudah dikonfirmasi infeksi dengan dua kali kultur selama periode dua tahun), dari tipe-tipe berikut ini: sepsis, pneumonia, meningitis, infeksi tulang atau sendi, atau abses organ interna atau cavitas tubuh (diluar otitis media, kulit permukaan atau abses mukosa, dan infeksi yang berhubungan dengan pemakaian kateter urin)

- Kandidiasis, esofageal atau paru-paru (bronkus, trakea, paru-paru)

- Kokidioidomikosis, diseminata (pada tempat lain atau tambahan di paru-paru atau leher atau kelenjar limfe hilus

- Kriptokokosis, ekstrapulmoner

- Kriptosporidiosis atau isosporiasis dengan diare menetap > satu bulan

- Penyakit siomegalovirus dengan awitan gejala pada usia > satu bulan (pada tempat selain hati, limpa, atau kelenjar limfe)

- Ensefalopati (paling tidak satu dari adanya temuan klinis yang progresif berikut untuk minimal dua bulan pada keadaan tidak adanya penyakit bersamaan selain infeksi HIV yang dapat menjelaskan temuan ini): a) gagal mencapai atau hilangnya milestone perkembangan atau hilangnya kemampuan intelektual, variasi dari skala perkembangan standar atau tes neuropsikologi; b) gangguan pertumbuhan otak atau adanya mikrosefali didapat pada pengukuran lingkar kepala atau adanya atrofi otak dengan pemeriksaan komputer tomografi atau magnetic resonance imaging (serial imaging dibutuhkan untuk anak usia $<2$ tahun): c) manifestasi defisit motor simetris didapat dengan dua atau lebih hal-hal berikut: paresis, refleks patologis, ataksia, atau gangguan berjalan

- Infeksi virus herpes simpleks yang menyebabkan ulkus mukokutan yang menetap pada > satu bulan; atau bronkitis, pneumonitis, atau esofagitis untuk berapa pun durasi yang terjadi pada anak $>$ usia satu bulan 
- Histoplasmosis, diseminata (pada tempat lain atau tambahan pada paru-paru atau leher atau kelenjar limfe hilus)

- Sarkoma kaposi

- Limfoma, primer, di otak

- Limfoma, kecil, sel noncleaved (Burkitt's), atau imunoblastik atau sel besar limfoma sel B atau fenotip imunologi yang tidak diketahui

- Mikobakterium tuberkulosis, diseminata atau ekstrapulmonar

- Mikobakterium, spesies lain atau spesies yang tidak diidentifikasi, diseminata (pada tempat lain atau tambahan pada paru-paru, kulit, atau leher atau kelenjar limfe hilus)

- Kompleks mikobakterium avium atau mikobakterium kansasii, diseminata (pada tempat lain daripada atau tambahan di paru, kulit, atau leher atau kelenjar limfe hilus)

- Pneumonia pneumonitis carinii

- Lekoensefalopati multifokal progresif

- Sepsis (nontifoid) salmonela, berulang

- Toksoplasmosis otak dengan awitan > usia satu bulan

- Sindrom wasting dengan tanpa adanya penyakit ikutan selain infeksi HIV yang dapat menjelaskan temuan berikut: a) kehilangan berat badan (BB) menetap $>10 \%$ dari BB awal ATAU b) memotong ke bawah pada minimal dua dari garis persentil berikut pada grafik berat usia menurut berat badan (contohnya, 95th, 75th, 50th, 25th, 5th) pada anak $\geq$ usia ATAU satu tahun c) < persentil 5 pada grafik berat badan menurut tinggi badan pada dua pengukuran konsekutif, $\geq$ 30 hari terpisah DITAMBAH a) diare kronis (contohnya, paling tidak dua buang air besar tiap hari selama $>30$ hari) ATAU b) demam yang dicatat (selama $\geq 30$ hari, intermiten atau konstan) 